\title{
Chemical Composition of Hyphal Wall of Phycomycetes
}

\author{
By MONIQUE NOVAES-LEDIEU, A. JIMENEZ-MARTÍNEZ \\ AND J. R. VILLANUEVA \\ Instituto de Biología Celular, C.S.I.C., Madrid-6, Spain
}

(Accepted for publication 19 December 1966)

\begin{abstract}
SUMMARY
Isolated hyphal walls from Phytophthora heveae, Pythium butleri and Saprolegnia ferax were hydrolysed and compared in quantitative composition. A high carbohydrate content was found in all these walls (80-90\%); also a small amount of glucosamine $(1-2 \%)$, lipids $(1-2 \cdot 5 \%)$ and protein. Quantitatively the cell walls differed appreciably in protein (1-11\%). Five neutral sugars (glucose, galactose, mannose, rhamnose, ribose) were detected by chromatography; glucose was always the main monosaccharide. From the results of acid-extraction of walls and enzymic hydrolysis it was concluded that a portion of cell-wall polysaccharide was cellulose $(30-45 \%)$. The amino acids found were those typical of normal protein hydrolysates and containing also hydroxyproline.
\end{abstract}

\section{INTRODUCTION}

Nabel (1939) found cellulose in cell walls of Pythium species by using microchemical methods. The presence of cellulose in cell walls of other Phycomycetes (Saprolegnia and Phytophthora species) was reported by Frey (1950). Crook \& Johnston (1962) made studies on cell walls of Saprolegnia ferax and Phytophthora cactorum and compared the compositions with those of other fungi and yeasts. Quantitative results on the chemical composition of cell walls of Phycomycetes have been reported recently by Bartnicki-García (1966) for Phytophthora parasitica and P. cinnamomi and by Mitchell \& Sabar (1966) for two Pythium species.

Bartnicki-García \& Lippman (1966) obtained protoplasts from two Phytophthora species by using a crude preparation of cellulase from a Streptomyces sp. In an attempt to obtain protoplasts of Phytophthora heveae, Pythium butleri and Saprolegnia ferax we have used a preparation of cellulase from Trichoderma lignorum. We have found occasionally that vacuoles are liberated but there is always a thin layer of cell wall which prevented the liberation of protoplasts. Our enzyme complex has protease and $\beta(1 \rightarrow 3)$ glucanase activities, and hydrolyses crystalline cellulose and carboxymethyl-cellulose (Nicolás, 1965: Villanueva, 1966). Our finding that the cell walls of our Phycomycetes were not completely hydrolysed by our enzyme preparations strongly suggested that some components other than that cellulose were present in the cell walls. To examine this possibility we have studied the chemical composition of $P$. heveae, $P$. butleri and $S$. ferax; the results obtained are reported in this paper. 


\section{METHODS}

Organisms and growth conditions. The three organisms of which cell walls were studied were Phytophthora heveae, Pythium butleri and Saprolegnia ferax kindly given to us by Commonwealth Mycological Institute, Kew, England. Stock cultures were maintained on agar slopes containing a medium of glucose and potato.

The organisms were grown in the medium GAE which consists of two solutions A and B. Solution A: glucose, 10 g.; asparagine, 1 g.; Difco yeast extract, 0.5 g.; water, $200 \mathrm{ml}$. This solution was autoclaved separately, three times for $30 \mathrm{~min}$. at $100^{\circ}$. Solution B: $\mathrm{K}_{2} \mathrm{HPO}_{4}, 0.5 \mathrm{~g}$.; $\mathrm{MgSO}_{4} .7 \mathrm{H}_{2} \mathrm{O}, 0.5 \mathrm{~g}$.; $\mathrm{FeSO}_{4} .5 \mathrm{H}_{2} \mathrm{O}, 0.01 \mathrm{~g}$; water, $800 \mathrm{ml}$. This solution was first adjusted to $\mathrm{pH} 7.2$ with $\mathrm{NaOH}$ and then autoclaved at $120^{\circ}$ for $30 \mathrm{~min}$. Solution $B(800 \mathrm{ml}$.) was added to solution A (200 ml.).

A suspension of mycelium obtained directly from a slope was used to inoculate $750 \mathrm{ml}$. of GAE medium contained in $3000 \mathrm{ml}$. conical flasks. Cultures were incubated on a reciprocating shaker for $72 \mathrm{hr}$ at $28^{\circ}$. Organism was harvested by filtration through a sintered glass-filter, washed well with distilled water and stored at $4^{\circ}$.

Preparation of cell-wall material. Various assays were made to select the best methods for breakage of each organism.

Pythium butleri mycelium ( $2 \mathrm{~g}$. wet wt) was homogenized in a Waring blender with $100 \mathrm{ml}$. distilled water for $1.5 \mathrm{~min}$. The resulting suspension was passed through a Ribi Cell fractionator (Sorvall) under a pressure of $35,000 \mathrm{lb} / \mathrm{sq}$. in. The organism was centrifuged at $800 \mathrm{~g}$ for $3 \mathrm{~min}$. and the supernatant fluid, consisting mainly of cytoplasmic debris, discarded. The 'cell-wall' fraction was washed five times with distilled water and centrifuged down at $800 \mathrm{~g}$. To remove remaining impurities from the cell walls the suspensions were again disintegrated as described above, centrifuged at $800 \mathrm{~g}$ for $3 \mathrm{~min}$. and the supernatant fluids discarded. The cell walls were washed five times with $1 \%(\mathrm{w} / \mathrm{v}) \mathrm{NaCl}$ and finally five times with water by centrifugation at $800 \mathrm{~g}$.

Phytophthora heveae (1-2 g. wet wt) was placed in the cup of a Braun cell homogenizer using no. 12 ballotini beads and treated for $7 \mathrm{~min}$. at full speed. The supernatant fluids were separated and the beads washed several times with $M$-sucrose solution. These washings were added to the first supernatant fluids containing the cell-wall fraction, and the cell walls recovered by centrifugation for $5 \mathrm{~min}$. at $800 \mathrm{~g}$. The pellet was washed five times with $10 \%(\mathrm{w} / \mathrm{v})$ sucrose and finally four or five times with water. As this procedure was not effective enough for breakage a further disintegration for $5 \mathrm{~min}$. was done; cytoplasmic debris were removed by centrifugation twice with $10 \%(\mathrm{w} / \mathrm{v})$ sucrose, then water, $1 \%(\mathrm{w} / \mathrm{v}) \mathrm{NaCl}$ and finally water.

Saprolegnia ferax mycelium (1 g. wet wt) was suspended in $13 \mathrm{ml}$. water and broken by treatment in a MSE ultrasonic disintegrator for 6-7 hr at 1.5 A. In some cases the disintegration was prolonged up to $10 \mathrm{hr}$ to obtain complete breakage of vacuoles. After treatment cytoplasmic debris were removed by centrifugation at $800 \mathrm{~g}$ for $3 \mathrm{~min}$. and the cell walls were washed five times in $1 \%(\mathrm{w} / \mathrm{v}) \mathrm{NaCl}$ and five times in water. The cell walls preparations were lyophilized and stored over $\mathrm{P}_{2} \mathrm{O}_{5}$ at $20^{\circ}$.

The course of breakage and purification of cell walls were followed by phase-contrast microscopy. The examination in the electron microscope of the isolated walls showed that they were practically free from cytoplasmic material. 


\section{Chemical analyses}

Amino sugars. Three types of hydrolysates were prepared in sealed tubes at $105^{\circ}$ with $2 \mathrm{~N}-\mathrm{HCl}$ for $4 \mathrm{hr}, 4 \mathrm{~N}-\mathrm{HCl}$ for $18 \mathrm{hr}$, and $6 \mathrm{~N}-\mathrm{HCl}$ for $24 \mathrm{hr}$. The $\mathrm{HCl}$ was removed in vacuum over $\mathrm{NaOH}$ pellets. The residue was dissolved in warm water and any insoluble material was separated by centrifugation. Neutral sugars were removed by passage of the hydrolysate through column of Dowex $50\left(\mathrm{H}^{+}\right)$resin and elution with $\mathrm{M}-\mathrm{NH}_{4} \mathrm{OH}$. The total hexosamine content was estimated by the method of Rondle \& Morgan (1955). Amino sugars were resolved by one-dimensional paper chromatography (Whatman no. 1) with $n$-butanol + pyridine $+0 \cdot 1 \mathrm{~N}-\mathrm{HCl}(5+3+2$ by vol.) as solvent. Hexosamines were located by using a modification of the Elson-Morgan reagent (Partridge, 1948).

Protein. The protein content of the wall preparations was estimated by three methods: (a) By the method of Lowry, Rosebrough, Far \& Randall (1951), performed on cold $\mathrm{N}-\mathrm{KOH}$ extracts of walls, with a standard curve obtained for serum albumin. (b) By the ninhydrin method (Moore \& Stein, 1954) in $6 \mathrm{~N}-\mathrm{HCl}$ hydrolysates, with leucine as standard. With the reactive ninhydrin-hydrindantine hexosamine yields a colour similar to that of amino acids. The interference was overcome in the following way: samples of all wall hydrolysates were used for the reaction of Moore \& Stein and other samples for the reaction of Rondle \& Morgan, as described above to determinate the hexosamine content in these hydrolysates. The reaction of Moore \& Stein was performed on glucosamine to make a standard curve. From the total colour (extinction at $570 \mathrm{~m} \mu$ ) obtained with ninhydrin was subtracted the colour corresponding to amino sugars. $(c)$ By the micro-Kjeldahl procedure. From the total nitrogen was subtracted the nitrogen corresponding to the amino sugars.

Amino acids. One to $10 \mathrm{mg}$. dry wt. cell walls were heated in $0 \cdot 1-1 \mathrm{ml} .6 \mathrm{~N}-\mathrm{HCl}$ in sealed tubes for $24 \mathrm{hr}$ at $105^{\circ}$. Excess $\mathrm{HCl}$ was removed in vacuum over $\mathrm{P}_{2} \mathrm{O}_{5}$ and $\mathrm{NaOH}$. Whatman paper no. 1 was used for chromatography. One-dimensional chromatograms were run for $18 \mathrm{hr}$ with $n$-butanol + formic acid + water $(75+15+10$, by vol.). Arginine, lysine and histidine were eluted with water from chromatograms and separated by electrophoresis on Whatman no. 1 at $\mathrm{pH} 11.5 ; 0.5 \mathrm{M}$-carbonate buffer $(750 \mathrm{v} ; 3 \mathrm{hr})$, before spraying. In the same way aspartic acid, serine and glycine were separated at $\mathrm{pH} 2.25$ (formic acid + acetic acid buffer) Glutamic acid and threonine were separated at $\mathrm{pH} 6 \cdot 5$ : pyridine + acetic acid + water buffer $(100+4+900$, by vol.). Two-dimensional chromatograms were wetted first with phenol + water $(80+20$, by vol.) in the presence of $\mathrm{KCN}$ and $\mathrm{NH}_{3}$; then with $n$-butanol + formic acid + water solvent. To detect the amino acids $0 \cdot 2 \%(\mathrm{w} / \mathrm{v})$ of ninhydrin in acetone was used. The intensity of colour and the size of spots of hydrolysate were compared with spots produced by known amounts of amino acids. Cysteine and cystine were detected on chromatograms as cysteic acid after oxidation with molybdate $+\mathrm{H}_{2} \mathrm{O}_{2}$. To detect proline and hydroxyproline $0.2 \%(\mathrm{w} / \mathrm{v})$ isatine in $4 \%(\mathrm{w} / \mathrm{v})$ acetic acid in acetone was used, followed by Ehrlich's reagent for hydroxyproline.

Sugars. The anthrone procedure as described by Chung \& Nickerson (1954), with glucose as standard, served to determine the total amount of hexosan present in intact walls. Identification and approximate estimation of monosaccharides was done by paper chromatography of various hydrolysates: $\mathrm{N}-\mathrm{HCl}$ at $105^{\circ}$ for $45 \mathrm{~min} ., 2 \mathrm{hr}$, $4 \mathrm{hr}, 6 \mathrm{hr}$. Excess $\mathrm{HCl}$ was removed in a desiccator over $\mathrm{NaOH}$. The paper chroma- 
togram (Whatman no. 1) was run with $n$-butanol + acetone + water $(4+5+1$, by vol.) for $24 \mathrm{hr}$. Sugars were detected with aniline phthalate. Glucose was assayed with a purified glucose oxidase reagent (glucostat 'special' Worthington Biochemical Corp., Freehold, New Jersey, U.S.A.).

Uronic acids. To detect uronic acids, the walls were hydrolysed as described by Gancedo, Gancedo \& Asensio (1966). The hydrolysates were chromatographied on Whatman no. 1 paper using ethyl acetate + pyridine + acetic acid + water $(5+5+1+3$, by vol.; Fischer \& Dörfel, 1955). A naphthoresorcinol reagent was used to detect uronic acids.

Lipids. Lipids were isolated by the method of Dr G. Ballesta (personal communication) which involves three extractions. The cell walls were first treated with $80 \%$ methanol at $70^{\circ}$ for $1 \mathrm{hr}$. Then, after drying in vacuum the residue was extracted by refluxing with ether, three times, and the extracts combined. This fraction constitutes the lipids of the first extraction. The second extraction was performed with ethanol + ether $+\mathrm{HCl}(50+50+1$, by vol.), and the third extraction with ethanol +ether + chloroform $(10+40+50$, by vol.). The products of the second and third extractions were mixed and this constitutes the lipids of the second fraction.

Phosphorus. Total phosphate was estimated by the method of Fiske \& SubbaRow as described by Umbreit, Burris \& Stauffer (1957).

\section{RESULTS}

Amino sugars. Hexosamines were detected in the three Phycomycetes (Table 1). The greatest hexosamine content was found in hydrolysates with $4 \mathrm{~N}-\mathrm{HCl}$ at $105^{\circ}$ for $18 \mathrm{hr}$. The drastic hydrolysis $6 \mathrm{~N}-\mathrm{HCl}, 24 \mathrm{hr}$ at $105^{\circ}$, caused $30-35 \%$ destruction.

Proteins. The protein content of mycelial walls estimated by the methods described showed important differences for Saprolegnia ferax (1-1.8\%), whereas similar values were obtained for Phytophthora heveae (5-6\%) and Pythium butleri (11-12\%) (Table 1). It is interesting to observe that for the three Phycomycetes the values found with the ninhydrin procedure was smaller than that found with the micro-Kjeldahl procedure. A possible explanation of this finding might be that some destruction of amino acids took place during hydrolysis, especially in presence of sugars. Twodimensional paper chromatography of cell-wall hydrolysates resolved 17 amino acid (probably 18) spots with variable intensity according to organisms, as shown in Table 2. No attempts were made to separate leucine from isoleucine. Pythium butleri contained $5-10 \%$ of hydroxyproline, whereas only a small amount was found in $P$. heveae and $S$. ferax. The unknown amino acid spots reported by Crook \& Johnston (1962) and Bartnicki-García (1966) with three Phytophthora species were not observed in the present work.

Carbohydrates. The main components (80-90\%) of the hyphal wall dry weight of the organisms studied were carbohydrates anthrone positive (glucose as standard; Table 1). Estimation of monosaccharide constituents of wall polysaccharides was done with various types of hydrolysates, but in no case was the sugar recovery complete. Some hydrolysis were insufficient to dissolve the wall completely, whereas in others a part of the wall carbohydrate was destroyed. Paper chromatography of hydrolysates revealed glucose as the main sugar component, and only very small amounts of other hexoses, pentoses and methyl pentoses (sometimes only traces) were detected in the three Phycomycetes (Table 3). 
Glucose was further characterized by treating the hydrolysates with purified glucose oxidase. The amount of glucan calculated from the glucose obtained by this method was smaller than the total carbohydrate values obtained by the anthrone procedure performed directly on intact walls. It is interesting that galactose was found in Pythium butleri, exclusively in hydrolysates with $\mathrm{N}-\mathrm{HCl}$ for $45 \mathrm{~min}$. and in Phytoph-

Table 1. Principal components of cell walls of Phytophthora heveae, Pythium butleri and Saprolegnia ferax

\begin{tabular}{|c|c|c|c|}
\hline \multirow{5}{*}{$\begin{array}{l}\text { Total-N (micro-Kjeldahl) } \\
\text { Protein (ninhydrin) } \\
\text { Protein }(\mathrm{N} \times 6 \cdot 25)^{*} \\
\text { Protein (Lowry) }\end{array}$} & \multicolumn{3}{|c|}{$\begin{array}{c}\text { P. heveae } \underset{\%}{\text { P. butleri }} \text { dry wt. cell wall } \\
\text { Serax }\end{array}$} \\
\hline & 1.08 & 2.02 & 0.42 \\
\hline & $4 \cdot 6$ & 10.7 & 1.3 \\
\hline & 5.6 & 11.9 & 1.8 \\
\hline & 6.7 & 11 & $\mathbf{1} \cdot \mathbf{1}$ \\
\hline $\begin{array}{l}\text { Total carbohydrates } \\
\text { (anthrone) }\end{array}$ & 90 & 81 & 93 \\
\hline $\begin{array}{l}\text { Glucosamine (Rondle \& } \\
\text { Morgan) }\end{array}$ & $2 \cdot 3$ & $1 \cdot 3$ & $1 \cdot 7$ \\
\hline $\begin{array}{l}\text { Phosphorus (as } \mathrm{H}_{2} \mathrm{PO}_{3} \text { ) } \\
\text { 1st fraction of lipids } \\
\text { 2nd fraction of lipids }\end{array}$ & $\begin{array}{l}0 \cdot 26 \\
1 \cdot 2 \\
1 \cdot 3\end{array}$ & $\begin{array}{l}0 \cdot 44 \\
1 \cdot 8 \\
0 \cdot 83\end{array}$ & $\begin{array}{l}0.36 \\
0.5 \\
0.5\end{array}$ \\
\hline
\end{tabular}

Table 2. Amino acids of cell walls of Phytophthora heveae, Pythium butleri and Saprolegnia ferax

\begin{tabular}{|c|c|c|c|c|}
\hline \multicolumn{5}{|c|}{ Grading of amounts* } \\
\hline++++ & +++ & $\stackrel{++}{++}$ & + & Traces \\
\hline Ala & $\begin{array}{l}\text { Pro, Thr } \\
\text { Val } \\
\text { Leu-Ileu }\end{array}$ & $\begin{array}{l}\text { Cys, Asp } \\
\text { Ser, Gly } \\
\text { Glu }\end{array}$ & $\begin{array}{l}\text { Lys, Arg } \\
\text { Hypro, Phe } \\
\text { Tyr }\end{array}$ & $\begin{array}{l}\text { His } \\
\text { Met }\end{array}$ \\
\hline \multirow[t]{2}{*}{$\begin{array}{l}\text { Lys, Asp } \\
\text { Ser, Thr } \\
\text { Ala }\end{array}$} & $\begin{array}{l}\text { Gly, Hypro } \\
\text { Pro, Val }\end{array}$ & $\begin{array}{l}\text { Cys, Glu } \\
\text { Tyr } \\
\text { Leu-Ileu }\end{array}$ & Arg, Phe & $\begin{array}{l}\text { His } \\
\text { Met }\end{array}$ \\
\hline & $\begin{array}{l}\text { Arg } \\
\text { Glu, Thr } \\
\text { Ala, Pro } \\
\text { Val } \\
\text { Leu-Ileu }\end{array}$ & $\begin{array}{l}\text { Cys, Lys } \\
\text { Asp, Ser } \\
\text { Gly, Phe }\end{array}$ & $\begin{array}{l}\text { Hypro } \\
\text { Tyr }\end{array}$ & $\begin{array}{l}\text { His } \\
\text { Met }\end{array}$ \\
\hline
\end{tabular}

* Amino acids in percentage: over $10 \%$ of wall protein $(++++) ; 5-10 \%(+++) ; 2-5 \%$ $(++) ; 1-2 \%(+)$; less than $1 \%$ (traces).

Table 3. Monosaccharides in cell walls of Phytopththora heveae, Pythium butleri and Saprolegnia ferax

\begin{tabular}{|c|c|c|c|c|c|}
\hline & Galactose & ${ }_{\text {Gra }}^{\text {Glucose }}$ & $\begin{array}{l}\text { Mannose } \\
(\%)^{*}\end{array}$ & Rhamnose & Ribose \\
\hline $\begin{array}{l}P . \text { heveae } \\
P . \text { butleri } \\
S . \text { ferax }\end{array}$ & $\begin{array}{c}+ \\
+ \\
\text { Traces }\end{array}$ & $\begin{array}{l}++++++ \\
++++++ \\
++++++\end{array}$ & $\begin{array}{c}+ \\
+ \\
\text { Traces }\end{array}$ & $\begin{array}{l}+ \\
+ \\
+\end{array}$ & $\frac{+}{+}$ \\
\hline
\end{tabular}

* Monosaccharides in percentage: over $80 \%(++++++), 0.5-1 \%(+)$ less than $0.5 \%$ (traces) 
thora heveae in hydrolysates with $\mathrm{N}-\mathrm{HCl}$ for $2 \mathrm{hr}$. It is possible that stronger hydrolysis would destroy galactose.

Some spots with a low $R_{F}$ appear in hydrolysates assayed in the study of monosaccharides. These spots could be oligosaccharides. To study this possibility we chromatographed the hydrolysates obtained by treatment with $\mathrm{N}-\mathrm{HCl}$ at $105^{\circ}$ for $45 \mathrm{~min} ., 1$ and $2 \mathrm{hr}$ using the same solvent described above for sugars but the running time of the solvent was $48 \mathrm{hr}$. Thus we could detect cellobiose $R_{\theta}: 0 \cdot 21$ and, laminaribiose $R_{\theta}: 0 \cdot 34$. On the other hand, gentibiose $R_{\theta}: 0 \cdot 11$ and laminaritriose $R_{\theta}: 0 \cdot 09$ were not identified by this method, but there was always a spot with $R_{\theta} 0 \cdot 10$ in the chromatograms. Gentiobiose, laminaritriose, cellobiose and laminaribiose were separated and characterized by chromatography for $36 \mathrm{hr}$ using the same solvent described above to investigate the presence of uronic acids. The $R_{\theta}$ values obtained in this system were; gentiobiose 0.56 , laminaritriose 0.63 , cellobiose 0.67 and laminaribiose $\mathbf{0} 83$. Small amounts of other oligosaccharides not well resolved appeared in the chromatograms.

Uronic acids were not detected in the special hydrolysates made as described under methods.

Phosphorus. Determination of total phosphorus (as metaphosphate) indicated a low phosphate content (Table 1). The nature of the phosphate components of the cell walls is not known.

Lipids. Small amounts of lipids in the first and second fractions were detected in the walls of the three Phycomycetes studied.

Cell-wall degradation with $\beta$-glucanases. Three $\beta$-glucanases preparations were used to investigate the presence of glycosidic linkages: $\beta(1 \rightarrow 3)$ glucanase, $\beta(1 \rightarrow 6)$ glucanase and cellulase. $\beta(1 \rightarrow 3)$ glucanase from Streptomyces RA was kindly given to us by Dr Rodríguez Aguirre. This preparation had been filtrated through a column of DEAE-cellulose and was free from $\beta(1 \rightarrow 6)$ and $\beta(1 \rightarrow 4)$ glucanases and $\beta$-glucosidase activities. Crude $\beta(1 \rightarrow 6)$ glucanase was a gift from Dr E. T. Reese; this preparation was obtained by precipitation with acetone from culture fluids of Penicillium brefeldianum $\mathrm{QM} 1872$ and it had high $\beta(1 \rightarrow 3)$-glucanase, $\beta$-glucosidase and low $\beta(1 \rightarrow 4)$ glucanase activities. A crude preparation of cellulase with a low $\beta$-glucosidase activity was obtained by us from culture fluids of Trichoderma lignorum. The products of enzymic hydrolysis of walls were investigated by paper chromatography as described above for acid hydrolysates. Controls were used in all these assays, consisting of cell-wall suspensions in buffer and the given enzyme preparation previously boiled for $10 \mathrm{~min}$. Liberation of sugars could not be observed in any of these controls.

Only small amounts of glucose and laminaribiose could be detected when cell walls of Phytophthora heveae, Pythium butleri and Saprolegnia ferax were treated with $\beta(1 \rightarrow 3)$ glucanase in $0.05 \mathrm{M}$-citrate buffer, $\mathrm{pH} 4.5$ at $40^{\circ}$, for 7 or $14 \mathrm{hr}$. On the other hand, glucose and gentiobiose were obtained by treating the walls with the $\beta(1 \rightarrow 6)$ glucanase for $4 \mathrm{hr}$ in a similar way to that described by Reese, Parrish \& Mandels (1962). The highest yield of glucose and gentiobiose was obtained from the walls of $S$. ferax. Treatment with the crude preparation of cellulase $\left(2\right.$ or $12 \mathrm{hr}$ at $40^{\circ}$ in $0.05 \mathrm{M}$-citratephosphate buffer, $\mathrm{pH}$ 5.4) was more dramatic and nearly complete hydrolysis of the walls was obtained after $12 \mathrm{hr}$ of treatment; paper chromatograms of $2 \mathrm{hr}$ hydrolysates always revealed high amounts of cellobiose and glucose and a low amount of laminari- 
biose. Under identical experimental conditions the amounts of cellobiose and glucose increased in the order: P. butleri, $P$. heveae and S. ferax. Thus, the enzymic hydrolysis shows also the existence of at least three types of glycosidic linkages: $\beta(1 \rightarrow 3)$, $\beta(1 \rightarrow 4)$ and $\beta(1 \rightarrow 6)$.

Hydrolysis of hyphal walls polysaccharides. The rate of hydrolysis of the cell walls of the three fungi considered in this work was compared with the data obtained in a similar hydrolysis of crystalline cellulose (Whatman cellulose powder) as described by Bartnicki-García (1966). The proportions soluble carbohydrate: dry cell wall are shown in Table 4. Soluble carbohydrate was estimated by the anthrone method after hydrolysis at $105^{\circ}$ with $\mathrm{N}-\mathrm{HCl}$ for different times. It can be concluded that there were at least two different types of glucan in the walls studied. One type of glucan was quickly solubilized by hydrolysis in $\mathrm{N}-\mathrm{HCl}$ and the other one, like cellulose, was very resistant to hydrolysis. The insoluble material after 2,4 and $6 \mathrm{hr}$ hydrolysis was soluble in Schweizer's reagent and was precipitated by acidification. From these results it can be concluded that this material is cellulose. The approximate proportions of glucan non-cellulosic in the walls studied can be obtained subtracting the value of hydrolyzed crystalline cellulose after $6 \mathrm{hr}$ from the approximate values of total glucan solubilized during the same time. These values expressed as \% dry weight of wall are: Phytophthora heveae $54 \%$ (36); Pythium butleri 58\% (23), and Saprolegnia ferax $51 \%$ (42); (figures in brackets are the corresponding ratio cellulose: dry wall).

\section{Table 4. Estimation of soluble carbohydrates after hydrolysis of cell walls of Pythium butleri, Phytophthora heveae and Saprolegnia ferax}

Cellulose and cell walls of $P$.butleri, $P$.heveae and $S$. ferax were hydrolysed with N-HCl for different times. Soluble carbohydrate was then estimated by the method of the anthrone (Chung \& Nickerson, 1954).

\begin{tabular}{|c|c|c|c|c|c|c|}
\hline \multicolumn{7}{|c|}{ Time of hydrolysis (hr) } \\
\hline $0 \cdot 25$ & $0 \cdot 50$ & 1 & 2 & 4 & 5 & 6 \\
\hline \multicolumn{7}{|c|}{$\%$ soluble carbohydrate: dry wall } \\
\hline 0.9 & $2 \cdot 0$ & $3 \cdot 3$ & $4 \cdot 1$ & $5 \cdot 5$ & $6 \cdot 1$ & \\
\hline $40 \cdot 1$ & $49 \cdot 2$ & 55.9 & $59 \cdot 4$ & 61.9 & $63 \cdot 2$ & 63 \\
\hline $41 \cdot 1$ & $49 \cdot 4$ & $54 \cdot 2$ & $56 \cdot 8$ & $58 \cdot 2$ & $59 \cdot 0$ & 59 \\
\hline $40 \cdot 8$ & $50 \cdot 2$ & $53 \cdot 5$ & $54 \cdot 8$ & $55 \cdot 2$ & $56 \cdot 1$ & 57 \\
\hline
\end{tabular}

\section{DISCUSSION}

Three different methods are described in this paper for obtaining cell walls of Phytophthora heveae, Pythium butleri and Saprolegnia ferax. Only the finding that different methods were required for breakage of each one of these fungi suggested that their cell walls have some differences in their structure and chemical composition. However no significant differences between the cell walls of these fungi were found by electron microscopy. The most significant difference in the chemical composition of the cell walls studied was found in their protein content which follows the pattern: protein in wall of $S$. ferax $<P$. heveae $<P$. butleri. The protein(s) of the walls contained all normal amino acids and hydroxyproline. The presence of this amino acid has been described previously in the walls of S. ferax and Phytophthora species (Crook \& Johnston, 1962; Bartnicki-García, 1966), higher plants (Lamport \& North- 
cote, 1960) and algae (Punnet \& Derrenbacker, 1966). These findings suggested that hydroxyproline is characteristic of cellulosic cell walls.

The amounts of glucosamine, ribose, rhamnose, mannose and galactose in the cell walls studied were very small and it is difficult to evaluate the structural importance of these components in the wall. These minor components might be important in haptens of the cell walls antigens. Mannose, glucosamine and ribose have been also detected in small amounts by Crook \& Johnston (1962) and Bartnicki-García (1966) in walls of different species of cellulosic fungi. The presence of rhamnose and galactose has not been reported in these fungi.

Three different sorts of glycosidic linkages were detected in the cell walls studied by partial hydrolysis with $\mathrm{HCl}$ or with three $\beta$-glucanases. The low activity of the $\beta(1 \rightarrow 3)$ glucanase on the walls could be due either to the special disposition of $\beta(1 \rightarrow 3)$ glycosidic linkages in the polysaccharide or to the low activity of the partially purified enzyme (Potgieter \& Alexander, 1966) or to the existence of only small quantities of $\beta(1 \rightarrow 3)$ glycosidic units. However, the last hypothesis can be discarded due to the laminaribiose and laminaritriose formed in the mild acid hydrolysis and it can be concluded that they constitute an important part of the polysaccharide. On the other hand the only liberation of glucose and gentiobiose by crude $\beta(1 \rightarrow 6)$ glucanase can be due to either a higher activity of the $\beta(1 \rightarrow 6)$ glucanase than of the other glucanases or to a high $\beta$-glucosidase activity of our enzyme preparation. If this was the case, gentiobiose might be more resistant to $\beta$-glucosidase hydrolysis as the activity of this enzyme differs very much on the oligosaccharide used as substrate (Reese \& Mandels, 1963). The liberation of laminaribiose, cellobiose and glucose by crude cellulase preparation was as expected from the enzymic activities shown by our preparation.

The presence of cellulose in the walls of the three fungi was shown by the high proportion of cellobiose liberated by a crude cellulase. It was confirmed by the finding of one sort of glucan very resistant to $\mathrm{HCl}$ hydrolysis, soluble in Schweitzer's reagent and precipitable from this solution by acid. Bartnicki-García (1966) has also detected cellulose, $\beta(1 \rightarrow 3)$ and $\beta(1 \rightarrow 6)$ glycosidic linkages in the walls of Phytophthora species. In addition Mitchell \& Sabar (1966) have shown cellulose in the cell walls of Pythium myriotilum.

The complete chemical composition and structure of the walls studied is not yet known. However we know that there are at least three sorts of linkages in their polysaccharide(s). The hydrolysis studies showed that there are two sorts of glucans. One of them soluble and the other one insoluble (cellulosic-like) under our conditions of hydrolysis; it is possible that the soluble glucan is linked to the cellulosic-like glucan. On the other hand, the whole wall protein was solubilized under the conditions required to solubilize the soluble glucan; this finding does not discard the possible existence in cellulosic fungal cell walls of a glucan-protein complex, as it has been reported in the walls of yeasts (Korn \& Northcote, 1959). More work is needed to clarify these hypotheses and to determinate the number and disposition of $\beta(1 \rightarrow 3)$, $\beta(1 \rightarrow 6)$ and $\beta(1 \rightarrow 4)$ glycosidic linkages.

The authors are indebted to Dr $\mathrm{M}^{\mathrm{a}} \mathrm{J}$. Rodríguez Aguirre for a gift of $\beta(1 \rightarrow 3)$ glucanase and to Dr E. T. Reese for supplying us $\beta(1 \rightarrow 6)$ glucanase and gentiobiose, laminaritriose and laminaribiose testiges. 


\section{REFERENCES}

BARTNICKI-GARCIA, S. (1966). Chemistry of hyphal walls of Phytophthora. J. gen. Microbiol. $42,57$.

BARTNICKI-GARCIA, S. \& LIPPMAN, E. (1966). Liberation of protoplasts from the mycelium of Phytophthora. J. gen. Microbiol. 42, 411.

Chung, C. W. \& Nickerson, W. J. (1954). Polysaccharide synthesis in growing yeasts. J. biol. Chem. 208, 395.

CroOK, E. M. \& Johnston, I. R. (1962). The qualitative analysis of the cell walls of selected species of fungi. Biochem. J. 83, 325 .

FisCHER, F. G. \& DöRFEL, H. (1955). The paper chromatographic separation and determination of hexuronic acids. Z. physiol. Chem. 301, 224.

Frey, R. (1950). Chitin und Zellulose in Pilzzellwänden. Ber. schweiz. bot. Ges. 60, 199.

Gancedo, J. M., Gancedo, C. \& Asensio, C. (1966). Uronic acids in fungal cell walls. Biochem. $Z$. 346, 328.

LAMPORT, D. T. \& NoRTHCOTE, D. H. (1960). Hydroxyproline in primary cell walls of higher plants. Nature, Lond. 188, 665.

Lowry, O. H., Rosebrough, N. J., FarR, A. L. \& Randall, R. J. (1951). Protein measurement with the Folin phenol reagent. J. biol. Chem. 193, 265.

MrtChell, R. \& SABAR, N. (1966). Autolytic enzymes in fungal cell wall. J. gen. Microbiol. $42,39$.

MOORE, S. \& STEIN, W. H. (1954). A modified ninhydrin reagent for the photometric determination of amino acids and related compounds. J. biol. Chem. 211, 907.

Nabel, K. (1939). Úber die Membran niederer Pilze, besonders von Rhizidiomyces bivellatus nov. spez. Arch. Mikrobiol. 10, 515.

NICOLÁs, G. (1965). Algunos aspectos fisiologicos de hongos hiperparastios. Ph.D. Thesis, Facultad de Ciencias, Universidad de Madrid.

Partridge, S. M. (1948). Filter-paper partition chromatography of sugars. Biochem. J. 42, 238.

Potgieter, H. J. \& AleXANDER, M. (1966). Susceptibility and resistance of several fungi to microbial lysis. J. Bact. 91, 1526.

PunNet, T. \& DerRenbacker, E. C. (1966). The amino acid composition of algal cell walls. J. gen. Microbiol. 44, 105.

REESE, E. T. \& M. MANDELs (1963). Advances in Enzyme Hydrolysis of Cellulose and Related Materials. London: Pergamon Press.

Reese, E. T., Parrish, F. W. \& Mandels, M. (1962). $\beta$-D-1,6-glucanases in fungi. Can. J. Microbiol. $8,327$.

RoNDle, C. J. M. \& MoRgan, W. T. J. (1955). The determination of glucosamine and galactosamine. Biochem. J. 61, 586.

UMBreit, W. W., Burris, R. H. \& Stauffer, J. F. (1957). Manometric Techniques. Minneapolis U.S.A.: Burgess Publishing Co.

Villanueva, J. R. (1966). Protoplasts of Fungi. In The Fungi. Ed. by G. C. Ainsworth \& A. S. Sussman, vol. 2, p. 2. New York: Academic Press. 